\title{
To: National Association of Evangelicals
}

John Allen Chalk

Follow this and additional works at: https://scholarworks.harding.edu/hst-chalk-personal

\section{Recommended Citation}

Chalk, J. A. (1969). To: National Association of Evangelicals. Retrieved from https://scholarworks.harding.edu/hst-chalk-personal/ 6671 
March 26, 1969

National Association of Evangelicals

P. O. Box 28

Wheaton, Illinois

Dear Sirs:

Please send me all available information, as well as registration forms, for your 1969 annual convention to be held in Cincinnati, Ohio.

Your attention to this request will be personally appreciated.

Sincerely yours,

John Allen Chalk

Radio Evangelist

JAC: $h m$ 